378.147::811.163.4(410)

https://doi.org/10.18485/msc_saopstenja.2018.48.1.ch15

Laura TODD

Владимир ЗОРИЋ

Прегледни рад

University of Nottingham

Примљен: 23. 10. 2018.

Прихваћен: 03. 12. 2018.

\title{
ЈУЖНОСЛОВЕНСКИ ЈЕЗИЦИ У ВЕЛИКОЈ БРИТАНИЈИ У КОНТЕКСТУ КРИЗЕ ХУМАНИСТИКЕ - СРПСКИ/ХРВАТСКИ ЈЕЗИК НА УНИВЕРЗИТЕТУ У НОТИНГЕМУ
}

\begin{abstract}
Овај текст се бави малом, али виталном академском енклавом српског језика и културе на Универзитету у Нотингему. У првом делу ће у кратким цртама бити изложена историја наставе српског језика на овом британском универзитету, као и тренутна позиција тог језика у оквиру постојећих студијских програма. У другом делу рада ћемо објаснити изазове са којима се тренутно сусрећемо и изложити њихову политичку и економску позадину. У трећем делу ћемо указати на неке правце деловања који би могли консолидовати овај предмет и створити једну групу филолога отвореног духа, која би допринела сарадњи Велике Британије и Србије.

Кључне речи: српскохрватски језик, Универзитет у Нотингему, традиција, криза ху-
\end{abstract} манистике, тржиште, постколонијалност, класна припадност, Брегзит

Словенски језици се у Нотингему предају већ више од једног века, што је за британску славистику прилично дуг период. Зачетник је извесни Василиј (Басил) Слепченко, Рус из Јекатеринодара (данас Краснодар) који је доспео у Енглеску пред почетак Првог светског рата и одлучио да се не врати, те је у јесен 1915. године на Универзитетском колеџу у Нотингему, који је тада још увек деловао као огранак Универзитета у Лондону, покренуо курс руског језика. ${ }^{1}$ Утемељивач јужне славистике у Нотингему је један виспрени Словенац, Јанко Лаврин, који је на катедри радио од 1918. до 1952. године и осим руског повремено држао часове српског језика (почев од 1919. годи-

${ }^{1}$ Malcolm V. Jones, Slavianskii mir: The Story of Slavonic Studies at the University of Nottingham in the Twentieth Century, Ilkeston: Bramcote Press 2009, str. 13-14. 
не). ${ }^{2}$ Јужну славистику је консолидовала професорка Моника Партриџ, у чије је време, од 1952. до 1982. године, српскохрватски постао део студиј-ског програма, и то као обавезни други страни језик. ${ }^{3}$ Коначни облик су јој дали професор Дејвид Норис и Питер Херити у чије су време, осамдесетих и деведесетих година двадесетог века, ова два језика у складу са духом времена постали изборни, а не обавезни, али је зато српскохрватски језик, са књижевношћу и културом, добио статус засебног студијског програма. Славистички одсек у Нотингему је имао срећу да су ове четири личности са интересовањем за јужну славистику имале дуге каријере у Нотингему, да су биле и управници катедре, и да су стога имале прилику да своје замисли спроведу у дело. У том смислу, треба им одати признање што су, свако на свој начин, допринели томе да данас у Нотингему имамо једну ширу катедру, која не покрива само руски језик и културу, што је добро само по себи, а у тренутним тржишним условима такође представља несумњиву предност у односу на друге установе. ${ }^{4}$

Српски језик се на Универзитету у Нотингему у континуитету предаје од 1971. године. Током тих готово пола века разликују се два периода. У првом периоду, за време Монике Партриџ, установљен је систем лектората на основу уговора са Универзитетом у Загребу. Према уговору, загребачка катедра за енглески језик је сваке године слала у Нотингем по једног свог члана да предаје српскохрватски (хрватскосрпски) језик, а трошкове је сносио Универзитет у Нотингему. Заузврат, Универзитет у Загребу је обезбеђивао смештај за студенте из Нотингема на студијском боравку у Југославији, укључујући и туторе, који су по правилу били ранији лектори у Нотингему. У другом периоду, за време Дејвида Нориса, установљен је другачији систем из разлога како финансијских тако и политичких. Наиме, због мањег броја студената, загребачки лектори су коштали Универзитет у Нотингему много више него лектори руског, а са распадом Југославије су све више почели да инсистирају на апсолутној посебности хрватског језика. Зато је 1994. године дошло до потпуног заокрета. Сарадња је усмерена на Универзитет у Београду, а лекторат је преведен у хонорарни, а касније и стални уговор који је склопљен са професорком Владиславом Рибникар, некадашњом шефицом катедре за Општу књижевност и теорију књижевности у Београду. Професорка Рибникар је у наставу српског језика унела велико педагошко искуство и емпатију и током скоро четврт века рада са студентима значајно унапредила како наставне

\footnotetext{
${ }^{2}$ Ibid., cтр. 32, 40-41.

${ }^{3}$ Ibid., стр. 79.

${ }^{4}$ Internet stranica Celebrating 100 Years of Russian and Slavonic Studies in Nottingham: People, Places, Tradition https://www.nottingham.ac.uk/CLAS/About/News-and-Events/RSSGallery/index. aspx (postavljeno 21. 10. 2016./poslednji pristup 17. 10. 2016.). Видети такође: Malcolm V. Jones, “А Nest of Slavists at Nottingham in the First Half of the Twentieth Century", Slavonic and East European Review, Vol. 93, No. 3 (July 2015), str. 525-541 i "Slavonic Studies in the United Kingdom Since the Second World War: A Personal View," u: Brogi Bercoff, Giovanna et al. Beiträge zur Geschichte der Slawistik in den nichstslawischen Ländern, Vienna: Verlag der Österreichischen Akademie der Wissenschaften 2005, str. 267-301.
} 
методе тако и материјале, од којих се већина користи и данас. ${ }^{5}$ То је допринело популарности српског језика и створило солидну базу за будући рад.

За разлику од српскохрватског, словеначки језик је у Нотингему од почетка, 1974. године, био присутан у облику лектората који су кофинансирали Универзитет у Нотингему и Универзитет у Љубљани. Овај лекторат је због недовољног броја студената недавно премештен на Школу за славистичке и источноевропске студије у Лондону, али лингвистички радови професора Питера Херитија на Универзитету у Нотингему остају један од камена темељаца за словеначке студије у свету. ${ }^{6}$

Под називом српски/хрватски језик, српски се на Универзитету у Нотингему може учити у оквиру двопредметних студија (Joint Honours, односно симетричне студије два језика: $50 \%$ - 50\%), у оквиру тропредметних студија (Combined Honours, односно српски језик у комбинацији са још два предмета, који могу, али не морају бити језици: $40 \%-40 \%-40 \%$ ), у оквиру такозване major-minor комбинације (асиметричне студије два језика: $80 \%-40 \%$, при чему је удео српског мањи), и, напослетку, као изборни односно помоћни предмет (број кредита зависи од индивидуалног интересовања). У релативно скорој прошлости су постојале и једнопредметне студије српског језика (Single Honours, 100\%), али током последњих неколико година нису у понуди због смањеног интересовања. Последња диплома једнопредметних српских студија је додељена 2016. године.

Српски језик се у оквиру ових студијских програма предаје на свим нивоима - од почетног (прва година), преко средњег (друга година) до завршног (четврта година) - и студира се заједно са низом предмета из књижевности, филма и историје јужнословенских народа. Студенти који ове предмете бирају као изборне, могу се определити за језик или културу, с тим што се ови други предмети раде са изворима и у оригиналу и преводу како би били приступачни и за оне који не уче језик. На трећој години, студенти српског језика као дипломског програма проводе део године у Србији и похађају наставу српског као страног језика на Филолошком факултету.

Треба рећи нешто кратко и о студентима српског језика на Универзитету у Нотингему. Већина студената до српског језика долази преко руског, који је много распрострањенији на универзитетима, а предаје се и у средњим школама, па су многи имали прилику да га раније студирају. Њима је у интересу да осим руског овладају још једним словенским језиком и Универзитет у Нотингему је један од свега неколико британских универзитета на којима им се пружа таква прилика. Тим студентима су основи словенске граматике (падежи, глаголске промене, глаголски вид) већ познати и стога брже савладавају српски језик. Са друге стране, они се суочавају са изазовом привидних

${ }^{5}$ У том погледу, највећи значај имају засебни уџбеници за српски и хрватски језик Владиславе Рибникар и Дејвида Нориса, Complete Serbian, London: John Murray Learnings 2010 i Teach Yourself Croatian, London: Hodder Arnold 2003. Осим тога, треба поменути и њихову „пастирску” бригу о нотингемским студентима на студијском боравку у Србији, као и предани рад на јачању институционалних веза са Универзитетом у Београду и на успостављању веза са српском дијаспором у Великој Британији.

${ }^{6}$ Peter Herrity, Slovene: A Comprehensive Grammar, London: Routledge 2000. 
сличности између руског и српског језика, што понекад доводи до мешања граматичких облика и значења појединих речи. У том смислу, познавање руског језика је од велике користи предавачима српског језика на Универзитету у Нотингему јер им омогућава да брзо препознају и разреше међујезичке недоумице.

За разлику од неких других западноевропских земаља, већина студената српског језика у Нотингему нису деца или унуци досељеника у Велику Британију, већ махом Британци чији преци нису имали никакве везе са Балканом. Њих не мотивишу ни финансијски ни породични разлози, већ чиста животна радозналост, жеља за откривањем нових простора, а понекад и случајни контакти, пријатељства, емотивне везе. Са таквим студентима је лакше и лепше радити, а неки од њих су постигли запажене резултате на нивоу факултета, па и универзитета. Додуше, код неких од њих би почетни ентузијазам спласнуо са првим тешкоћама савладавања падежа и глаголских промена па је било и случајева одустајања. Ипак, с обзиром да се српски језик предаје у малим групама, знатно мањим од група за друге језике, студенти добијају више пажње и времена, атмосфера је приснија и стога је општи ниво успеха и личног задовољства релативно висок.

Сви студенти српског језика су током боравка у Србији створили снажне везе са том земљом и многи од њих одржавају те односе и посећују пријатеље и након дипломирања. Такође је занимљиво приметити у којој мери заједничко искуство учења језика у Србији уједињује наше студенте. Они су обично задовољнији својим студијама, постижу боље резултате на испитима и студијски боравак у Србији виде као једну од највећих предности свог универзитетског живота.'

Осим редовне наставе, студенти српског језика имају и културни програм: у складу са финансијским могућностима, Универзитет у Нотингему организује гостовања предавача, писаца и уметника из Србије и других земаља бивше Југославије, а и сами студенти су укључени у организацију оваквих догађаја. На пример, једно књижевно вече се припрема неколико недеља унапред тако што студенти на часу преводе изабране одломке из релевантног књижевног дела гостујућег писца и ти преводи се затим штампају и деле у облику брошуре.

На основу овог кратког прегледа, могао би се извести закључак да је српски језик на Универзитету у Нотингему у добром положају и да му је будућност сигурна. Чињеница је, међутим, да ове студије, као и читава хуманистика, пролазе кроз период кризе. Број запослених у настави српског језика на Универзитету у Нотингему је пао са троје на двоје, односно са 2,8 на 1,5 (прерачунато по уделу пуног радног времена), једнопредметне студије

${ }^{7}$ Phil Davis, Windows on Russia and Eastern Europe: Graduates Tell Their Stories of Life, Work and Survival, Ilkeston: Bramcote Press 2013. 
су обустављене, а неки предмети се више не држе због смањења броја запослених. Нажалост, ни шира слика, на државном нивоу, није нарочито ведра. Славистика на британским универзитетима се претходних година суочила са бројним тешкоћама и многе катедре су затворене, смањене или спојене са другим катедрама.

У Великој Британији је акредитовано 136 установа високог образовања, што старих (,,red brick universities”), што нових (из двадесетог века), па и оних најновијих (које су настале из политехника, односно виших школа, законом из 1992. године). Од тог броја, словенски језици, пре свега руски, предају се на нивоу студијских програма - дакле, не само као изборни или вечерњи курсеви - на 17 универзитета. Од тих 17 универзитета, српски језик се предаје, заједно са хрватским, на само два универзитета: на Универзитетском колеџу у Лондону, под окриљем Школе за славистичке и источноевропске студије, и на Универзитету у Нотингему. Додуше, српски језик се предаје у још једној високошколској установи у Лондону, на Универзитету у Вестминстеру. Међутим, тај универзитет нема стандардне додипломске програме, већ нуди вечерњи курс, који углавном похађа дипломатско и војно особље британске владе са конкретним задужењима на Балкану.

Треба истаћи да је у не тако давној прошлости стање било знатно боље: стални лекторати или у најмању руку језички курсеви постојали су још и на универзитетима у Кембриџу, Бирмингему, Ланкастеру и Дарему. Међутим, током последњих четврт века ти лекторати су један за другим затварани и тако је књига српског језика на британским универзитетима спала на два слова: Лондон и Нотингем.

Шта је довело до тог крајње незавидног стања? Покушаћемо да набројимо основне факторе и њихове последице.

Један од битних узрока кризе филологије лежи у постколонијалном менталитету Велике Британије, односно у културнополитичкој оријентацији на сопствени језик. Наиме, 2004. године, лабуристичка влада је одлучила да страни језици постану необавезан предмет за GCSE (General Certificate of Secondary Education) у средњој школи. Још увек није јасно зашто је та одлука донета, али се, опште узев, сматрало да језици нису од виталног значаја у модерном образовању, које треба да се усредсреди на математику, науке и технологију, што ће рећи на предмете који ће са већом вероватноћом обезбедити да млади људи могу да дођу до посла. Ова одлука говори много о британском ставу према студирању језика. У данашњем свету, у којем је енглески lingua franca науке, технологије и међународног бизниса, све чешће се поставља питање зашто би млади људи уопште требало да уче било који језик осим енглеског. Овај аргумент превиђа виталну чињеницу да међународна размена и сарадња захтевају не само просто разумевање на неком метајезику, већ такође и културно познавање партнера, што може да се научи једино кроз предмете хуманистике.

Ова одлука из 2004. године је била изузетно штетна за универзитетске филолошке студије јер је велика већина ученика одлучила да не студира језике, који се сматрају „тешким” и „бесмисленим, с обзиром на то да сви говоре 
енглески". То је довело до пада броја студената страних језика и култура на универзитету, што је нарочито погодило немачки језик, али није поштедело ни друге језике. ${ }^{8}$ Иако се српски језик не изучава у средњим школама у Великој Британији, пад студената других страних језика је посредно значио мањи број уписаних на двопредметне и вишепредметне студије (српски у комбинацији са другим страним језицима). Последице су очигледне и у широј популацији: Британци постају монолингвална нација. Недавна анкета Британског савета је показала да 62\% Британаца не говори ниједан страни језик, а само 38\% говори један страни језик (при чему 18\% говори два, а 6\% три страна језика). ${ }^{9}$ Битно је уочити да су многи у тој немонолингвалној популацији двојезични на основу породичног порекла; другим речима, одрасли су у породицама у којима су се говорили други језици, а енглески су користили у школи. Ова група, која долази из мултикултурног окружења, обично се чешће посвећује студирању страних језика.

Даље, руски језик, који, бар у Нотингему, представља главни пут ка српском језику, више се не сматра једнако битним као за време Хладног рата. Данас врло мало Британаца зна руски па су неразумевање и недостатак знања о том народу и свим другим народима у њиховој сфери утицаја више правило него изузетак. Ова ситуација се донекле променила након 2014. године, када је Русија поново призната као битан чинилац у међународној политици. Ипак, ново интересовање за Русију као глобалну силу није довело до покушаја бољег, суштинског разумевања те земље: медији се усредсређују на њена негативна својства, која се преносе и на бивше комунистичке/социјалистичке земље, а британска влада не ради много на томе да искорени те стереотипе. Дакле, то ново интересовање политичара и медија за словенске језике и културе је у великој мери разочарало универзитетске предаваче јер дневна политика поново преузима примат над хуманистичким промишљањем значаја разумевања страних култура.

Затим, ту су и економски узроци, међу којима је најбитнији нова, радикално тржишна концепција универзитета која знање дефинише као производ, а не као опште добро, и студенте као купце, а не као хуманистичку елиту друштва. Највећи искорак у том правцу направљен је 2010. године, када је конзервативна влада променила систем финансирања универзитета и овластила их да сами убирају средства преко школарина и распоређују их у складу са својим приоритетима (Шкотска је, додуше, изгласала да буде изузета). То је практично значило да држава и универзитети препуштају тржишту да одлучи који предмети су профитабилни, а који не, те да у складу са тиме артикулишу развојну стратегију, укључујући и оснивање односно укидање појединих дисциплина. Притом се превиђа да заснивање односно гашење дисциплине у једној конкретној универзитетској заједници није исто што и оснивање или

\footnotetext{
${ }^{8}$ Adams, Richard and Caelainn Barr, "A-level results: foreign languages suffer further slump”, The Independent, 16. avgust 2018.

9 "British Worst at Learning Languages", видети интернет страницу http:/esol.britishcouncil. org/content/learners/skills/reading/british-worst-learning-languages (последњи приступ 18. октобар 2018).
} 
затварање фирме. За квалитет студијског програма су пресудни искуство и традиција, који се не могу створити преко ноћи нити пресадити из неке друге средине, већ се граде током генерација преданог научног и наставног рада. У сваком случају, са увођењем пуних школарина, сви страни језици, а посебно они мањи, попут српског, нашли су се у зачараном кругу слободног трзишта. Мање уписаних студената доводи до смањења броја запослених, а смањење броја запослених доводи до новог смањења броја студената.

Као и многи други процеси у Великој Британији, ови неолиберални трендови у учењу језика у великој мери зависе и од класне припадности. Језици се и даље предају у приватним и селективним школама у које се уписују махом ученици из вишег и средњег слоја британског друштва. У радничкој и нижој класи, на језике се не гледа као на могући лични професионални избор, већ као на неку врсту разоноде која се повезује са „богатима”. Многи од тих младих људи ионако немају прилику да путују и питају се зашто би онда учили стране језике. Ученици средњих школа који долазе на Универзитет у Нотингем на „отворена врата” (периодичне групне посете универзитету) кажу да им се у средњим школама још увек говори да страни језици нису важни, да им неће обезбедити добар посао те да се морају усредсредити на науке. Међутим, на основу истраживања која су спровеле разне организације знамо да знање страног језика помаже да се пронађе бољи посао и тако доприноси бољој животној перспективи. Дакле, недостатак државне стратегије студирања језика и монолингвалност постају саставни део класних подела у Великој Британији и филолози константно морају да иду против матице како би разбили ове митове.

Сва ова политичка и економска превирања су достигла кулминацију 2016. године, када је Велика Британија на националном референдуму тесном већином (51.89\% према 48.11\%) изгласала да напусти Европску унију. Независно од различитих могућих разлога у прилог изласку из Европске уније, који су иначе и даље предмет политичких расправа, јасно је да је велики део кампање био заснован на промоцији британског изолационизма и националне супериорности који су гласачима из радничке класе продавани као утеха за њихов лош положај, као и на широко распрострањеној ксенофобији, поготово према такозваним источноевропским земљама. Иако Србија није чланица Европске уније, претпоставља се да ће престанак прилива европских фондова негативно утицати на све универзитете и да ће мере штедње највише погодити мале предмете. Такође, тренутно није јасно да ли ће бити угрожени и студијски програми попут Еразмуса који имају базу у Европској унији, али обухватају и друге земље, попут Србије.

III

Ова ситуација има занимљиве последице по наставу српског језика у Великој Британији. Велика Британија је двоструко забринута јер, с једне 
стране, политичко тежиште ставља на питање о томе како Русија утиче на Србију, а са друге стране, више не може да користи своје чланство у Европској унији као адут за повезивање са Србијом. Без сумње, Русија има велики утицај у Србији, али такође и у Црној Гори и Босни и Херцеговини. Прошле године, влада је успоставила посебну комисију у Дому лордова чији је задатак да размотри „британски однос са Западним Балканом након Брегзита”. ${ }^{10}$ Ова комисија се бави превасходно економским односима, али она такође представља сигнал да Велика Британија жели да задржи одређени утицај и у глобалној политици. Комисија је у почетку имала извесног успеха и састала се са председницима свих земаља у региону. Касније је њено деловање у великој мери маргинализовано због унутрашњих сукоба у Конзервативној партији. Али, независно од дневне политике, како се Велика Британија може надати да сачува присуство на Балкану ако је српски језик могуће студирати само на два универзитета и ако се историја региона може изучавати само на малом броју катедара? Управо су дипломирани студенти ти који треба да помогну наредним владама Велике Британије да разумеју значај сарадње са Србијом, не само из политичких разлога већ и због заједничких историјских и културних интереса.

Такође, током протекле године, учињени су озбиљни напори да се исправе грешке које су претходне владе направиле у образовној политици и језици су поново уведени као (полу)обавезни предмет. Учење страних језика је уведено и у основне школе, што је раније постојало само у приватним школама. Међутим, проблеми су и даље врло дубоки. Многи наставници који предају стране језике у основним школама заправо не говоре добро те језике, а запослени су јер нема довољно адекватних кандидата. Дефицит у тој професији је последица чињенице да мање студената уписује језичке програме.

Ово је један од главних разлога зашто се ми у Нотингему трудимо да сачувамо српски језик као студијску опцију, а не само као помоћни предмет. Наш задатак је отежан тиме што се студијски програми финансирају у складу са интересовањем студената које се мења из године у годину. На наше курсеве се током године углавном уписује тек мали број студената, али управо ти студенти кључно доприносе оном малом али значајном броју студената на државном нивоу који дипломирају са знањем српског језика и културе. На дуже стазе, то је од изузетног значаја, али у тржишном концепту високог образовања, где је тежиште на науци и технологији, тешко је водити овакву битку. Ипак, неколико чињеница нам је ишло у прилог и вреди се кратко осврнути на њих.

Најпре, Универзитет у Нотингему је имао срећу да након распада Југославије без већих трзавица сачува заједнички штокавски стандард под практично непромењеним називом: Serbian/Croatian. То је било од пресудне важности јер у Великој Британији, поготово у унутрашњости, заиста не постоји довољно моћан микроскоп који би изоловао српски, хрватски, босански и

\footnotetext{
${ }^{10}$ Видети интернет страницу Дома лордова, "Beyond Brexit: the UK and the Balkans Inquiry" https://www.parliament.uk/uk-and-the-balkans (последњи приступ 18. октобар 2018).
} 
црногорски стандард као посебне студијске програме. Тренутно се овај заједнички језички спектар централног Балкана предаје махом преко српског стандарда, а хрватски се уводи контрастивно, преко разлика. Студенти који се више интересују за хрватски стандард имају приступ материјалима на хрватском језику као и додатну подршку предавача. ${ }^{11}$

Повољна околност је и то што је Универзитет у Нотингему део Расел групе (Russell Group) универзитета која окупља 24 високошколске установе које знатна средства улажу у научно истраживање и у складу са тиме преузимају обавезу да одржавају и потпомажу постојеће дисциплине. Јужнословенски језици и културе, пре свега српски, интегрисани су у истраживачку мапу Универзитета у Нотингему већ неколико деценија. Током тог периода, предавачи су се поред наставе језика бавили и лингвистиком, књижевношћу и културном историјом, те објавили читав низ студија и учествовали у бројним међународним пројектима.

Такође, професорка Моника Партриџ је тестаментом оставила половину свог имања, 250.000 фунти, славистичком одсеку у Нотингему, са нагласком на јужној славистици, за подршку студентима и наставницима за студијска путовања, језичке курсеве и друге пројекте који унапређују сарадњу у словенском свету. Али, у тестаменту постоји клаузула по којој тај новац не може да се потроши као замена за основно финансирање (core funding); другим peчима, универзитет овај новац не може да искористи за лекторска места, што је сасвим разумљиво јер у супротном универзитет не би имао никакав мотив да улаже у српски језик. Стога се средствима Партриџ фондације заправо побољшава оно што универзитет нуди и студентима српског језика се даје мала компаративна предност у односу на студенте других језика.

На крају, навешћемо неколико билатералних мера којима би се у сарадњи са Универзитетом у Београду и министарствима просвете и културе Републике Србије српски језик на Универзитету у Нотингему могао консолидовати. Те мере се могу поделити на оне које припремају основу за универзитетске студије у секундарном образовању, на мере током универзитетских студија и након универзитетских студија. У сфери секундарног образовања постоји велики простор за сарадњу са српским имигрантским заједницама које су веома распрострањене у регији Мидландс, где се налази Универзитет у Нотингему. Српски језик би се у одређеним срединама и школама могао увести као матурски предмет (GCSE), чиме би се отворио простор за надградњу на универзитету. Даље, током универзитетских студија, студенти Универзитета у Нотингему већ имају одличан пријем на Филолошком факултету, како на редовним курсевима, тако и на Међународном састанку слависта у Вукове дане. Ипак, нека врста подршке настави у Нотингему би била од велике помоћи. То би могло да буде у виду сталног или периодичног лектората или редовних гостовања предавача са Филолошког факултета на Универзитету

${ }^{11}$ У периоду пре распада Југославије, користио се уџбеник српскохрватског језика Монике Партриџ Serbo-Croatian: Practical Grammar and Reader, London: McGraw-Hill 1964. У новије време, користе се засебни уџбеници за српски и хрватски језик Дејвида Нориса и Владиславе Рибникар Complete Serbian i Teach Yourself Croatian. 
у Нотингему. Након студија, било би изванредно корисно ако би дипломци Универзитета у Нотингему у Србији имали могућност стажирања, односно привремене лектуре на неком од одсека за англистику у Србији. То би им омогућило да, макар у првој фази своје каријере, буду оно што заправо и јесте позив филолога: културни амбасадори, компетентни посредници међусобног разумевања академских институција и читавих друштава.

\section{ЛИТЕРАТУРА}

Adams, Richard and Caelainn Barr, "A-level results: foreign languages suffer further slump", The Independent, 16. avgust 2018.

British Council, 2015. "British Worst at Learning Languages" http://esol.britishcouncil.org/content/learners/skills/reading/british-worst-learning-languages (последњи приступ 18. октобар 2018.)

Davis, Phil. Windows on Russia and Eastern Europe: Graduates Tell Their Stories of Life, Work and Survival, Ilkeston: Bramcote Press 2013.

Herrity, Peter. Slovene: A Comprehensive Grammar, London: Routledge 2000.

Jones, Malcolm V. "A Nest of Slavists at Nottingham in the First Half of the Twentieth Century", Slavonic and East European Review, Vol. 93, No. 3 (July 2015), str. 525-541.

-Slavianskii mir: The Story of Slavonic Studies at the University of Nottingham in the Twentieth Century, Ilkeston: Bramcote Press 2009.

- "Slavonic Studies in the United Kingdom Since the Second World War: A Personal View," u: Brogi Bercoff, Giovanna et al. Beiträge zur Geschichte der Slawistik in den nichstslawischen Ländern, Vienna: Verlag der Österreichischen Akademie der Wissenschaften 2005, pp. 267-301.

Norris, David, and Ribnikar, Vladislava. Complete Serbian, London: John Murray Learnings 2010.

-Teach Yourself Croatian, London: Hodder Arnold 2003.

Partridge, Monica. Serbo-Croatian: Practical Grammar and Reader, London: McGraw-Hill 1964.

Web stranica Celebrating 100 Years of Russian and Slavonic Studies in Nottingham: People, Places, Tradition https://www.nottingham.ac.uk/CLAS/About/ News-and-Events/RSSGallery/index.aspx (постављено 21. октобар 2016./ последњи приступ 17. октобар 2018.)

Web stranica Dom lordova, "Beyond Brexit: the UK and the Balkans Inquiry," https:/www.parliament.uk/uk-and-the-balkans (последњи приступ 18. октобар 2018). 
Laura Todd, Vladimir Zorić

\section{STUDYING THE SERBIAN LANGUAGE AT THE UNIVERSITY OF NOTTINGHAM IN THE CONTEXT OF THE CRISIS IN THE HUMANITIES}

\section{Summary}

The Slavonic section at the University of Nottingham has recently marked its first centenary (1915-2015). Over those hundred years, this section has developed the undergraduate and the postgraduate studies of the Russian language, literature and culture as its core subject, but also established its reputation in Serbian/Croatian studies, which is very rare in Slavonic departments in the United Kingdom. Serbocroatian (now Serbian/Croatian) at the University of Nottingham has a reach tradition in both teaching and research and it is also about to mark its centenary (1919-2019). Initially, the Serbian/Croatian programmes relied upon the university's partnership with the University of Zagreb but more recently (over the last thirty years) it collaborated with the University of Belgrade. In this paper, we are going to present a brief history of Serbocroatian (Serbian/Croatian) as an academic subject at the University of Nottingham and indicate some of the challenges faced by this subject in the wake of the crisis in the humanities in the twenty-first century. In particular, we are going to address the political, financial and institutional factors which are specific to the United Kingdom and which influence student recruitment and the shape of the language programmes alike. Also, we are going to identify some short-term strategies and long-term solutions which could consolidate the position of small languages at the British universities.

Key words: Serbocroatian, University of Nottingham, tradition, crisis in the humanities, market, postcoloniality, class identity, Brexit. 